\title{
Illuminating a Contorted Slab with a Complex Intraslab \\ Rupture Evolution during the 2021 Mw 7.3 East Cape, New \\ Zealand Earthquake
}

\author{
Ryo Okuwaki ${ }^{1,2,3, *}$, Stephen P. Hicks ${ }^{4,}=$, Timothy J. Craig ${ }^{3}$, Wenyuan Fan ${ }^{5}$, Saskia \\ Goes $^{4}$, Tim J. Wright ${ }^{3}$, and Yuji Yagi ${ }^{2}$ \\ ${ }^{1}$ Mountain Science Center, University of Tsukuba, Tsukuba, Ibaraki 305-8572, Japan \\ ${ }^{2}$ Faculty of Life and Environmental Sciences, University of Tsukuba, Tsukuba, Ibaraki 305-8572, Japan \\ ${ }^{3}$ COMET, School of Earth and Environment, University of Leeds, Leeds LS2 9JT, UK \\ ${ }^{4}$ Department of Earth Science and Engineering, Imperial College London, London SW7 2AZ, UK \\ ${ }^{5}$ Scripps Institution of Oceanography, UC San Diego, La Jolla, California 92093, USA
}

\section{Key Points:}

- A moment magnitude 7.3 2021 East Cape, New Zealand intraslab earthquake comprised multiple rupture episodes with different faulting styles

- The complex rupture comprises components of shallow trench-normal extension and unexpectedly, deep trench-parallel compression in slab

- The trench-parallel compression likely reflects stress rotation at a buoyancy contrast that drives slab contortion

\footnotetext{
${ }^{*}$ Equally contributing author

Corresponding author: Ryo Okuwaki, rokuwaki@geol.tsukuba.ac.jp
}

This article has been accepted for publication and $\overline{-}$ undergone full peer review but has not been through the copyediting, typesetting, pagination and proofreading process, which may lead to differences between this version and the Version of Record. Please cite this article as doi: 10.1029/2021GL095117.

This article is protected by copyright. All rights reserved. 


\begin{abstract}
The state-of-stress within subducting oceanic plates controls rupture processes of deep intraslab earthquakes. However, little is known about how the large-scale plate geometry and the stress regime relate to the physical nature of the deep-intraslab earthquakes. Here we find, by using globally and locally observed seismic records, that the moment magnitude 7.3 2021 East Cape, New Zealand earthquake was driven by a combination of shallow trench-normal extension and unexpectedly, deep trench-parallel compression. We find multiple rupture episodes comprising a mixture of reverse, strikeslip, and normal faulting. Reverse faulting due to the trench-parallel compression is unexpected given the apparent subduction direction, so we require a differential-buoyancy driven stress rotation which contorts the slab near the edge of the Hikurangi plateau. Our finding highlights that buoyant features in subducting plates may cause diverse rupture behavior of intraslab earthquakes due to the resulting heterogeneous stress state within slabs.
\end{abstract}

\title{
Plain Language Summary
}

A key type of tectonic boundary is where two plates collide with one sinking into the mantle beneath. These subduction zones generate the world's largest earthquakes. Quantifying stress in the subducting plate ("slab") is important because slabs drive the global plate-tectonic system, and large earthquakes can occur within them. These earthquakes can cause strong shaking, and, when occurring near cities, can lead to damage. However, mapping stress is challenging as we cannot directly "see" inside deep slabs. Our best indications of slab stress come from earthquakes themselves. A magnitude 7.3 earthquake north of New Zealand in 2021 generated a distinct pattern of seismic waveforms at seismometers installed worldwide. We used these seismic records to probe the earthquake, providing a new view of stress in subduction zones. We found the earthquake generated both vertical and horizontal motions along faults, driven by compressional and extensional stresses deep within the slab. The compressional part is oriented 90 degrees from the subduction direction, which is opposite to the usual compression in subduction zones. This unusual direction of compression can be explained by subduction of a thickened and buoyant part of the Pacific plate, known as the Hikurangi plateau. 


\section{Introduction}

Complex fault configurations and heterogeneous fault conditions, i.e. stress and strength states, govern earthquake rupture development and propagation (Avouac et al., 2014; Floyd et al., 2016; Elliott et al., 2016; Hamling et al., 2017). Such relations can be inferred from the fault geometry and long-term geodetic observations for shallow active faults (Simons et al., 2002; Williams et al., 2013; Elliott et al., 2016; Arai et al., 2016; Hamling et al., 2017; Hayes et al., 2018; Sippl et al., 2018). However, for intraslab earthquakes occurring below $\sim 50 \mathrm{~km}$ depth, these physical controlling factors are difficult to assess because of challenges to map structure at such depths, and the general lack of seismicity there (Wiens, 2001; Ranero et al., 2005; Page et al., 2016; Dascher-Cousineau et al., 2020; Gomberg \& Bodin, 2021). In particular, the internal stress state and its extensional-compression transition regime are often elusive in subducted slabs, although they directly impact intraslab earthquake occurrence and their faulting styles (Astiz et al., 1988; Ammon et al., 2008; Craig et al., 2014; Romeo \& ÁlvarezGómez, 2018; Sandiford et al., 2019, 2020; Ye et al., 2021). Thus, imaging the rupture processes of large, deep intraslab earthquakes offers a rare window to investigate the slab configuration, and to understand fault interaction and rupture evolution of these earthquakes, illuminating heterogeneous stress fields.

An intraslab moment magnitude $\left(M_{\mathrm{W}}\right) 7.3$ earthquake occurred offshore the East Cape in northern New Zealand on 4th March 2021, which was followed $\sim 4$ hours later by a series of the $M_{\mathrm{W}} 7.4$ and $M_{\mathrm{W}} 8.1$ earthquakes in the Kermadecs ( $900 \mathrm{~km}$ to the north) (GeoNet, 2021). The $M_{\mathrm{W}} 7.32021$ East Cape earthquake, which is the focus of this paper, may offer insight into the regional slab geometry because of its location and complex rupture process. The 2021 East Cape earthquake locates at the boundary between the southern end of Kermadec trench and the northern end of Hikurangi margin, where the Pacific plate subducts beneath the Australian plate and its convergence decreases and progressively rotates to oblique motion toward the south (Fig. 1) (Collot et al., 1996, 2001; Lewis et al., 1998; Wallace et al., 2009). The earthquake produced observable tsunami signals at tide gauges at the northern coast of New Zealand (GeoNet News, 2021), indicating seafloor deformation due to possible shallow slip. However, the reported centroid depth of the earthquake was $\sim 50 \mathrm{~km}$ (U.S. Geological Survey Earthquake Hazards Program, 2017; Duputel et al., 2012; Dziewonski et al., 1981; Ekström et al., 2012), and the focal mechanism indicates oblique-thrust motion, with the compressional axis oriented towards the north-south direction (Fig. 1) (U.S. Geological Survey Earthquake Hazards Program, 2017; Duputel et al., 2012; Dziewonski et al., 1981; Ekström et al., 2012). This compressional axis suggests the earthquake 
was not a simple shallow normal- or reverse-faulting event with the strike angle oriented parallel to the trench axis, as is typically seen in many subduction zones (Fig. 1) (U.S. Geological Survey Earthquake Hazards Program, 2017; Duputel et al., 2012; Dziewonski et al., 1981; Ekström et al., 2012). All these apparently inconsistent observations (GeoNet, 2021; GeoNet News, 2021) suggest a complex rupture process of the East Cape earthquake, possibly involving multiple faults at different depths.

Although the subduction-related deformation processes in the region south of East Cape have received a lot of scientific attention (e.g., Eberhart-Phillips \& Reyners, 1999; Reyners et al., 2006; Wallace et al., 2009; Mochizuki et al., 2021), the transition to the Tonga-Kermadec arc is less well understood. In the region north of East Cape, sporadic deep seismicity ( $>80-\mathrm{km}$ depth) contrasts with abundant shallow seismicity (<50-km depth) (Dziewonski et al., 1981; Ekström et al., 2012; GeoNet Moment Tensors, 2021; U.S. Geological Survey Earthquake Hazards Program, 2017; GeoNet, 2021). Most of the shallow earthquakes are normal faulting events within the top of the oceanic plate due to trench-normal extensional stress due to slab bending into the trench (Reyners \& McGinty, 1999; Henrys et al., 2006; Bassett et al., 2010). With these shallow earthquakes, the plate interface and the surrounding materials have been imaged down to $\sim 20 \mathrm{~km}$ depth (Davey et al., 1997; Bell et al., 2010; Bassett et al., 2010, 2016), but the lithospheric structure of the deep slab is poorly resolved. The apparent complex rupture process of the 2021 East Cape earthquake offers a unique opportunity to infer the stress regime associated with the deeper subduction process.

Here we show that the rupture process of the 2021 East Cape earthquake involves multiple rupture episodes, that can be fitted with a mixture of reverse, strike-slip, and normal faulting mechanisms. These episodes ruptured multiple faults through the subducted oceanic lithosphere at various depths. The earthquake initiated at approximately $70 \mathrm{~km}$ depth with an unexpected trench-parallel compressional reverse faulting mechanism, and followed by a slip episode at about $30 \mathrm{~km}$ depth, which is likely governed by more usual slab-bending trench-normal down-dip extension. Such a rupture process reflects a heterogeneous stress regime within the subducted slab, in response to a possible geometric change of the slab in depth due to either the subduction of a seamount associated with the Ruatoria debris slide (Lewis et al., 1998; Collot et al., 2001; Lewis et al., 2004), or a sharp change in slab buoyancy at the northern end of the subducting Hikurangi oceanic plateau.

This article is protected by copyright. All rights reserved. 


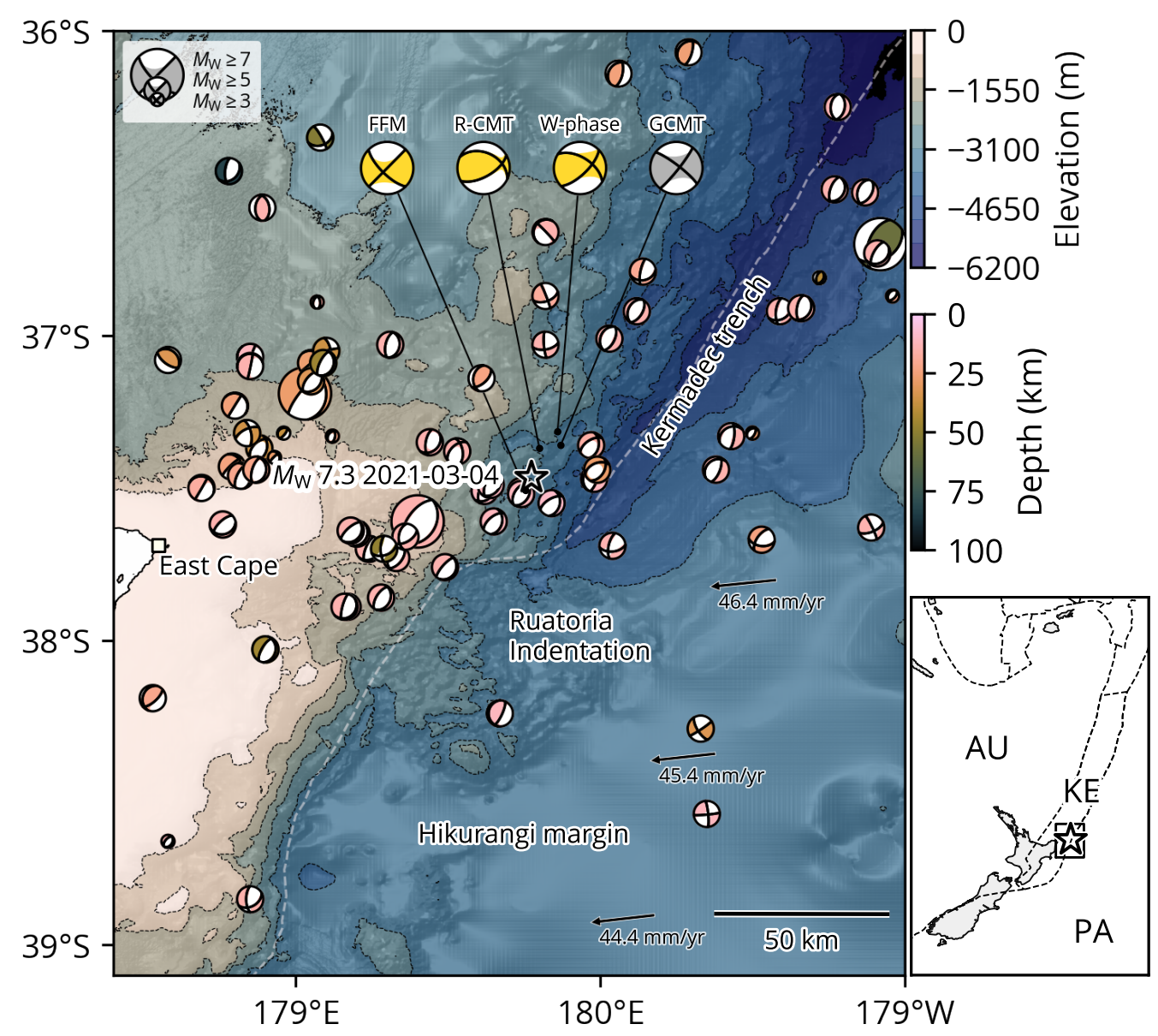

Figure 1. Seismo-tectonic overview of the study region in the north of East Cape, New Zealand. The star shows the relocated hypocenter of the $M_{\mathrm{W}} 7.32021$ East Cape earthquake. Beach balls are the lower-hemisphere stereographic projection of the moment tensor solutions before the 2021 East Cape earthquake, colored by depth (Dziewonski et al., 1981; Ekström et al., 2012). Yellow beach balls are the moment tensor solutions for the 2021 East Cape earthquake obtained by this study (FFM; Finite-fault model, R-CMT; regional centroid moment tensor, $W$-phase; $W$-phase moment tensor). Background contours display the bathymetry (Mitchell et al., 2012). The arrows show the relative plate motions with the convergence rate of the Pacific plate (PA) towards the fixed Australian plate (AU) (DeMets et al., 2010). The dashed line gives the approximate location of the subduction trench (e.g., Bassett et al., 2010). The right map shows the wider setting of the study region. The rectangle shows the area of the left map. The star marks the epicenter. The dashed lines are the plate boundaries (Bird, 2003) between the Pacific (PA), the Australian (AU) and the Kermadec (KE) plates. 


\section{Hypocenter, aftershock relocation, and initial source estimates}

We first determined the hypocenter of the East Cape earthquake by non-linear inversion of $P$ - and $S$-wave arrival times at regional distances using a $1 \mathrm{D}$ velocity model appropriate for the region north of East Cape (Text S1; Fig. S1). Our relocated epicenter lies along the trench axis, and is within $10 \mathrm{~km}$ of the GeoNet solution (GeoNet, 2021), and $35 \mathrm{~km}$ ENE of the U.S. Geological Survey National Earthquake Information Center (USGS-NEIC) solution (U.S. Geological Survey Earthquake Hazards Program, 2017) which is consistent with the USGS-NEIC epicenters being systematically shifted to the down-dip direction in subduction zones (e.g., Ye et al., 2017). Our maximumlikelihood hypocenter depth is $72 \mathrm{~km}$. Although this hypocenter depth may be thought to be inherently uncertain due to the sub-optimal station coverage, it provides an initial hypothesis for testing our results of the more complex rupture configuration later. If we instead fix our hypocentral depth at the fixed GeoNet/USGS estimates of 1012 km (GeoNet, 2021; U.S. Geological Survey Earthquake Hazards Program, 2017), the root-mean-square (RMS) residual of arrival times at the closest stations $(<200 \mathrm{~km})$ increases by $0.3 \mathrm{~s}$. Although the deeper hypocentral depth led to lower RMS value, the lower RMS value only represents a better data fit and does not reduce the nonuniqueness of the inverse problem, hence not equivalent to location uncertainty itself. The $68 \%$ confidence ellipsoid of our solution corresponds to an epicentral uncertainty of $0.03^{\circ}$ and $0.02^{\circ}$ in longitude and latitude, respectively; the depth uncertainty is \pm 9 km (Fig. S1). However, no depth phases were reported in the International Seismological Centre Bulletin for this earthquake (International Seismological Centre, 2021), presumably due to interference with the long source-time function.

Next, we located aftershocks of the 2021 East Cape earthquake the same way as for the mainshock. We focus on events reported by GeoNet (2021) occurring from March 4, 2021 to April 11, 2021 (1 week from the mainshock); (Fig. S2), which yields 622 events with magnitudes ranging from 1.5-6.2. To assure the robustness of the solutions, we remove earthquakes and their arrivals that: (1) were not manually reviewed by GeoNet (2021), (2) have maximum azimuthal gaps of more than 295 degrees, and (3) have fewer than at least 10 phase arrivals (Fig. S2). The median depth uncertainty of these aftershocks is $22 \mathrm{~km}$ (with $6 \mathrm{~km}$ standard deviation), and the median epicentral uncertainties are $0.05^{\circ}$ and $0.08^{\circ}$ in latitude and longitude, respectively. The aftershocks suffer large depth uncertainty due to their location outside of the regional network, which hampers an unambiguous determination of the total rupture area. However, we broadly identify both shallow $(<30 \mathrm{~km})$ and deep $(>50 \mathrm{~km})$ aftershocks, and 
such a depth distribution could be explained by our preferred rupture model of both shallow and deep ruptures in the downgoing lithosphere.

Using a Bayesian bootstrapping centroid-moment tensor (CMT) inversion of lowfrequency $(2.0-8.5 \mathrm{mHz})$ teleseismic waveforms for a single-point source (Text S2), we find a mean centroid depth of $53 \mathrm{~km}$, with a centroid position shifted $18 \mathrm{~km} \mathrm{NNE}$ of our relocated epicenter, and time shift from the origin time of $+5 \mathrm{~s}$ (Fig. S3). However, the CMT solution has a large non-double couple component (DC=15\%). Such a low DC component is likely caused by geometric complexities of the earthquake that may involve multiple faults within the subducted Pacific plate near the Hikurangi trench.

Finally, to test the hypothesised rupture complexity, we investigated the rupture process of the earthquake with a multi-point centroid moment tensor (R-CMT) inversion method using regional seismic waveforms (Text S3; Figs. S4 to S6). The approach can resolve the first-order features of a complex rupture with few assumptions. The later part of the $<25 \mathrm{~s}$ period surface waves on the horizontal components at stations within $\sim 400 \mathrm{~km}$ epicentral distance are poorly fit (Figs. S5 and S6) due to basin resonance effects (Kaneko et al., 2019). We find that the East Cape event can be best explained by two sub-events, with the largest sub-event $\left(M_{\mathrm{W}} \sim 7.3\right)$ at $50-70 \mathrm{~km}$ depth occurring 8-10 s after the origin time, and the second sub-event at 7-12 km depth and $6-8 \mathrm{~s}$ after the first sub-event. The second sub-event significantly increases waveform variance reduction by $16-23 \%$. The first sub-event has an oblique-reverse mechanism. Conversely, the second sub-event has a normal faulting mechanism. Overall, our R-CMT solution corroborates a complex rupture scenario involving at least two sub-events separated by $\sim 40 \mathrm{~km}$ in depth: one in the top of the Pacific plate, the other deep within the slab.

\section{Intermittent complex multiple rupture episodes with various focal mechanisms}

To better understand the rupture development, we applied a finite-fault potencydensity inversion method (Shimizu et al., 2020) to estimate the rupture evolution of the 2021 East Cape earthquake (Text S4). The method can flexibly accommodate multiple faults with different geometries rupturing during the same event, which are inferred from the spatiotemporal distribution of five-basis double-couple components of the potency-density tensors (Kikuchi \& Kanamori, 1991; Ampuero \& Dahlen, 2005). In our inversion formulation, the model parameters are objectively determined by minimizing Akaike's Bayesian Information Criterion (ABIC) (Akaike, 1980; Yabuki \& Matsu'ura, 1992), and we do not adopt non-negative constraints for slip vectors. Such a procedure can effectively prevent over- or under-smoothing of the source model as theo- 


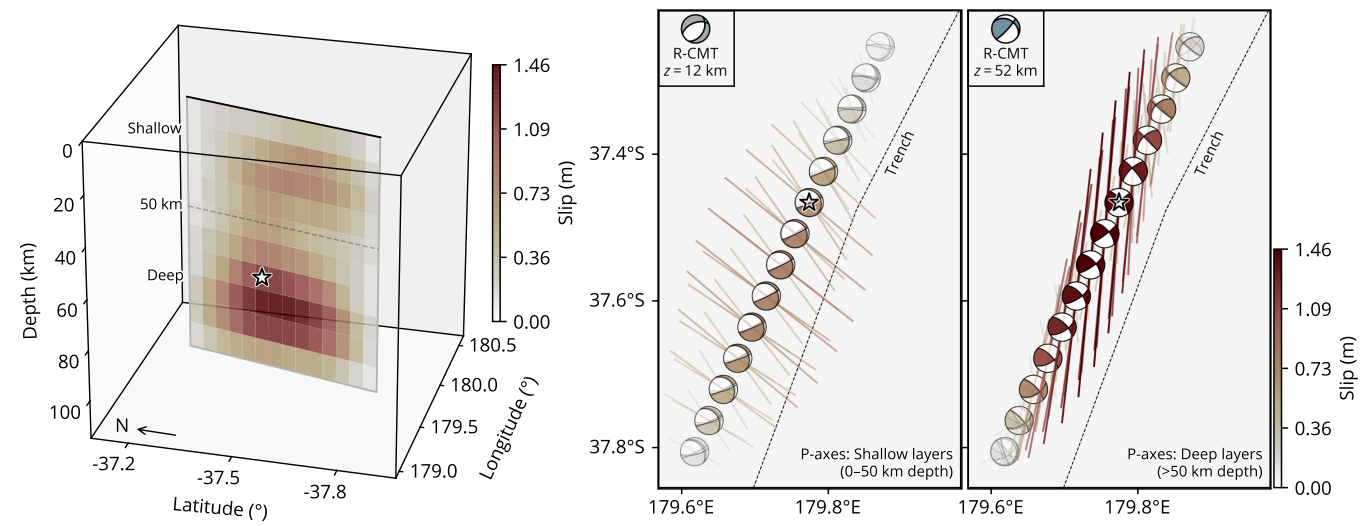

Figure 2. Static slip distribution. The left panel shows the total slip distribution in a 3D view, viewed from the south-west. The star represents our hypocenter. The black line shows the top of the model fault. The right panels show the map view of the slip distribution from shallow $(<50$ $\mathrm{km}$ ) and deep depths ( $\geq 50 \mathrm{~km})$, with beach balls representing double-couple components of the moment tensor solution (Fig. S7), and corresponding P-axis azimuths (bars scaled by slip). The moment tensor is calculated by integrating the slip-rate function for each basis component of moment tensor with respect to time at each sub-fault. The P-axis azimuth is extracted from the resultant double-couple solution for each sub-fault, which is represented by a lower-hemisphere stereographic projection. We show the beach balls from the slip patch corresponding to the fault element with the maximum slip within each given depth range. The inset shows the corresponding R-CMT solutions annotated with their depths $(z)$. The dashed line is the subduction trench (Bird, 2003). 
retically shown in Fukuda and Johnson (2008). Particularly, we flexibly solve the potency density in a finite-fault domain instead of regularizing the model with possible inaccurate subjective assumptions (e.g., positivity constraints, and the prescribed fault geometry). The method has proven effective at resolving complex earthquake ruptures in a variety of tectonic settings (Shimizu et al., 2020, 2021; Okuwaki et al., 2020; Hicks et al., 2020; Tadapansawut et al., 2021; Yamashita et al., 2021). In practice, we parametrize a $2 \mathrm{D}$ vertical model domain along a $200^{\circ}$ strike extending from 7 - to 107 $\mathrm{km}$ depth with a total of 140 source elements (sub-faults) (Fig. 2). This parameterization is guided by the observed cluster of the near-trench-parallel aftershocks (Fig. S2). Although it is difficult to resolve the absolute locations of slip surfaces due to insufficient spatial resolution of the teleseismic body waves used in our finite-fault modeling, in the 2D model domain, we solve the fault-normal and shear-slip vectors at each source element, which are independent of the model domain geometry. In other words, we solve for distributed sources in the model domain that may have any type of faulting mechanism required by the data. The model domain therefore allows multiple faulting episodes of the earthquake and does not necessarily indicate a single fault plane cutting through the lithosphere in a continuous rupture. Our preferred slip model suggests that the earthquake initiated at $72 \mathrm{~km}$ depth (Fig. S12), which yields variance reduction (VR) of waveform fitting $74 \%$, corroborating the relocated hypocenter and the R-CMT solution. We test possible model domain geometries that only cover some specific depths, but the finite-fault models of such model setups cannot adequately explain the observed waveforms (Fig. S12). We note that a 3-D parameterization would have been ideal for imaging this earthquake, but it is currently infeasible due to computational limits.

To further test our model, we also use the same dataset and model domain to invert a finite-fault model but restrict the subfaults to have the same strike and dip (Fig. S14). The results of our test show that in comparison to our preferred finite-fault model, fixing the focal mechanisms to the prescribed model plane has a much lower VR of $25 \%$. This exercise highlights the importance of permitting a complex rupture scenario when modeling this earthquake and shows that an overly simplified model would fail to explain even the first few seconds the direct $P$ waves (for example, first 5 s $P$ waves of XMAS and CRZF stations). These early $P$ waves are unlikely to be affected by water phases given the source depth. The water multiples should be incoherent with azimuth, given the variation in water depth around the source region. Such incoherent phases, that are not represented in the Green's functions used in our inversion, cannot translate into complexity in source time function. We also note that using a 1D velocity model for Green's functions without considering the simplifica- 
tion effects may introduce erroneous biases. Further, even using 3D velocity models to compute the Green's functions, the fidelity of the velocity models remains a source of uncertainty. For example, the local 3D velocity model (e.g., Eberhart-Phillips et al., 2010, 2020) may suffer uncertainties for the area near the 2021 event because of a lack of offshore stations for tomographic inversions. Our approach can address such assumptioninduced errors. We explicitly consider these effects by introducing an uncertainty term of the Green's function into the data covariance matrix in the inversion formulation (Yagi \& Fukahata, 2011). Such an approach has proven effective in reducing solution errors that are due to model oversimplifications (Yagi \& Fukahata, 2011; Minson et al., 2013; Duputel et al., 2014; Ragon et al., 2018).

Our preferred finite-fault model suggests that most slip occurred at 55 to 100 $\mathrm{km}$ depth and $\sim 15 \mathrm{~km}$ south of the hypocenter, releasing $69 \%$ of the total moment (Fig. 2). Another patch of slip is observed at $20-40 \mathrm{~km}$ depth, much shallower than the hypocentral depth and comprising $31 \%$ of the total moment. The deeper slip is dominated by an oblique strike-slip faulting mechanism. The shallow slip involves a mixture of normal and strike-slip faulting mechanisms. The finite-fault model leads to a moment estimate of $1.7 \times 10^{20} \mathrm{Nm}\left(M_{\mathrm{W}} 7.4\right)$. We evaluated the robustness and uncertainty of the finite-fault model by performing synthetic tests (Fig. S13). The result shows that both the slip pattern and the variation of faulting mechanism in the model domain are well reproduced. We will discuss in detail in a later section, but the focal mechanisms of the shallow and deep domains agree with the R-CMT solutions (Fig. 2), which show shallow normal faulting with the likely fault plane striking parallel to the trench axis and deep reverse faulting with the compressional axis orienting along the trench axis.

The rupture process of the East Cape earthquake involved deep- and shallowslip corresponding to different faulting types, which may be expressed as a few bursts of rupture episodes (e.g., E1 to E4). In this interpretation, the earthquake initiated as reverse faulting with a strike-slip component for the first $5 \mathrm{~s}$ (E1, Fig. 3). The rupture then propagated towards the south at $60-100 \mathrm{~km}$ depth, releasing $20 \%$ of the total moment and lasting for about $5 \mathrm{~s}$ (E2, Fig. 3). This episode was dominated by reverse faulting. The third episode (E3) simultaneously might have ruptured several fault patches from $5 \mathrm{~s}$ to $15 \mathrm{~s}$, including a shallow patch at $\sim 25 \mathrm{~km}$ depth and a deep patch $\sim 70 \mathrm{~km}$ depth (Fig. 3). The shallow part of E3 ruptured with a normal faulting mechanism, while the deep patch of E3 had a strike-slip mechanism. The last major episode (E4) ruptured a fault patch beneath the hypocenter for about $5 \mathrm{~s}$ with a dominant strikeslip focal mechanism (Fig. 3). We note that E4 is unique as its dominant mechanism 
suggests a strike-slip faulting style, whilst the E1 and E2 show reverse mechanisms (Fig. 3). The remaining 26\% of the total moment was released by slips at both shallow and deep regions, and the earthquake lasted for about $\sim 30 \mathrm{~s}$. Most of the seismic moment was released within $\sim 20 \mathrm{~s}$ in our finite-fault solution, consistent with the half-duration of the GCMT solution (10 s) (Dziewonski et al., 1981; Ekström et al., 2012), which seems typical as for other similar sized earthquakes (e.g., Duputel et al., 2013).

The four rupture episodes appear compact in size and seem to involve multiple faulting mechanisms at different depths. Given the varying focal mechanisms, the chaotic episodes likely do not result from the same continuous rupture front, but more likely represent segmented slip on different faults that may have interacted with, and triggered, each other. 

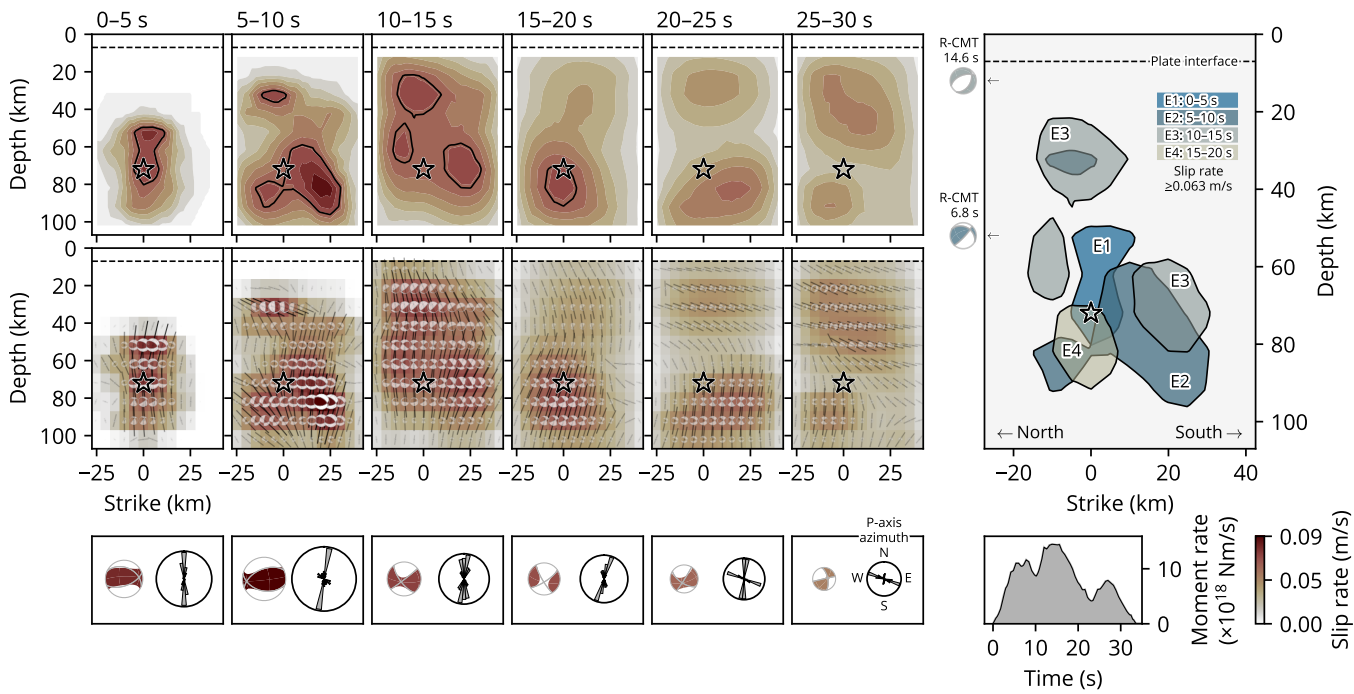

Figure 3. Slip evolution. The left panels show the cross sections of the spatio-temporal distribution of slip rate and the resultant moment-rate tensor solution, given in $5 \mathrm{~s}$ long windows. The moment tensor is calculated by integrating the slip-rate function for each basis component of moment tensor with respect to the corresponding time window at each sub-fault. The star represents the hypocenter. The dashed line is the top of the subducting plate (Bassett et al., 2010). The black contour highlights faster slip rates $(\geq 0.063 \mathrm{~m} / \mathrm{s} ; \geq 70 \%$ of maximum slip rate). The centroid moment tensor for each time window is shown at the bottom, together with the rose diagram of P-axis azimuths weighted by slip rate. The centroid moment tensor is calculated by integrating the slip-rate function for each basis component of moment tensor of all the sub-faults with respect to the corresponding time window and then constructing a final moment tensor from the integrations by spatially integrating the moment tensors from all the subfaults. All the beach balls of the moment-tensor solution are represented as a lower-hemisphere stereographic projection, not rotated according to the model geometry, but in map view. The right panel summarizes the sliprate evolution. The color for each episode (E1 to E4) corresponds to the time window. The minor slip-rate events within the final two time windows (20-30 s) are not slipping fast enough to plot a contour on the right panel. R-CMT solutions are also shown at the corresponding depths, with their time shift given relative to the hypocentral time. The right-bottom inset is the total moment-rate function from the finite-fault model. 
Our preferred finite-fault solution suggests a non-uniform moment release of the earthquake, which could be due to spatiotemporally disconnected rupture episodes (Figs. 3 and S15). Alternatively, the results could also represent two sub-events with longer durations. In this case, the deep sub-event initiates at the hypocenter and propagates toward south at $<2.5 \mathrm{~km} / \mathrm{s}$ until $15 \mathrm{~s}$ from the origin. The higher slip rate, seen during 15-20 s located around the hypocenter, can be a result of faster $<5 \mathrm{~km} / \mathrm{s}$ backpropagation from south to north. The shallow sub-event can be rather a continuous rupture propagating from deep $(50 \mathrm{~km})$ to shallow $(30 \mathrm{~km})$ depths during $0-15 \mathrm{~s}$ at a speed of $<2 \mathrm{~km} / \mathrm{s}$.

\section{Intraslab stress rotation in depth}

The source process of the 2021 East Cape earthquake could be characterized as multiple episodes rupturing from deep to shallow within the subducted slab (Fig. 2). The multi-fault rupture may have caused the small double-couple percentage in the moment tensor solution for the 2021 East Cape earthquake (e.g., 32\% in the GCMT solution), which is particularly evident for the deeper rupture domain in our finitefault solution (Figs. 3 and S7). Such a rupture process would involve a mixture of reverse and strike-slip displacement, which is akin to the $2000 M_{\mathrm{W}} 7.9$ Enggano intraslab earthquake that ruptured multiple faults at a similar depth leading to a $33 \%$ doublecouple component in its GCMT solution (Abercrombie et al., 2003). For the shallow slip episode of the 2021 East Cape earthquake, its focal mechanism shows a mixture of the normal faulting with a strike-slip component. The general trend of the aftershock distribution (Fig. S2) suggests that the fault plane striking toward the northeastsouthwest direction likely ruptured during the later phase of the earthquake. Although the limited station azimuth coverage could cause an artificially elongated aftershock distribution, the major axis of the uncertainty ellipse of the mainshock relocation, which shares the similar station coverage, is oriented W-E rather than SW-NE (Fig. S1). It is noteworthy that some aftershocks (U.S. Geological Survey Earthquake Hazards Program, 2017; Dziewonski et al., 1981; Ekström et al., 2012; GeoNet Moment Tensors, 2021) share similar focal mechanisms to the shallow rupture episode (Fig. S8). Given the near-trench location of the East Cape earthquake, there is some ambiguity regarding the exact faulting configuration. However, the aftershock distribution indicates that the shallow slip episode likely ruptured a normal fault within the downgoing plate. Additionally, in the absence of clear shallow slip with a reverse-faulting mechanism, this normal faulting episode likely caused the observed tsunami. 
The varying focal-mechanisms of the four slip episodes (E1-E4) show the compressional stress orientation (the P-axis orientation) of the East Cape earthquake rotated from the northwest-southeast direction to the north-south direction with a gap in slip and approximate stress transition depth at $\sim 50 \mathrm{~km}$ (Figs. 2 and 3). The normal faults of the shallow slip episodes striking northeast-southwest agree well with the extension in the upper part of the subducted plate due to the expected plate bending and pulling process (e.g., Astiz et al., 1988; Ammon et al., 2008; Craig et al., 2014; Romeo \& Álvarez-Gómez, 2018; Sandiford et al., 2020). Such a bending process seems to have caused most of the background seismicity in this region, which has predominant normal faulting mechanisms (Fig. 1; Reyners \& McGinty, 1999; Bassett et al., 2010). If the deep slip at 50-100-km depth during the East Cape earthquake was driven by the same bending-related process, we would expect a trench-normal P-axis orientation, which is typical for similar events at other subduction zones, where deep trenchparallel reverse faulting is observed (e.g., Okada \& Hasegawa, 2003; Ohta et al., 2011; Ye et al., 2012; Todd \& Lay, 2013; Ye et al., 2021). However, the deep slip patches of the East Cape earthquake (E1 and E2, and R-CMT Sub-event 1) have oblique-thrusting mechanisms, resulting in a trench-parallel compression. This perplexing P-axis orientation indicates an additional regional factor that may have modulated the rupture process of the East Cape earthquake.

The interactivity between various faulting episodes is a puzzling part of the East Cape earthquake. Subduction zone earthquakes may involve multiple disconnected subevents with different faulting types that can trigger and interact with each other (Ammon et al., 2008; Lay et al., 2013; Hicks \& Rietbrock, 2015; Lay et al., 2020). For the East Cape earthquake, our preferred finite-fault model does not show a continuous rupturing path from the deep to shallow episodes (Figs. 2 and 3). The shallow rupture E3 is separated by $\sim 40 \mathrm{~km}$ from the deep episodes and started $\sim 5 \mathrm{~s}$ later (Fig. 3 ), suggesting an apparent rupture speed of $\sim 8 \mathrm{~km} / \mathrm{s}$ if the rupture was continuous. Such a rupture speed would be close to the local $P$-wave speed (Table S1), which is unlikely. More likely, slip episodes E1 and E2 triggered the following shallow episode E3 due to either the static and/or dynamic stress change from the initial deep rupture. A stress transition or strength contrast within the slab can work as an inhomogeneous barrier (Das \& Aki, 1977; Aki, 1979) to smooth propagation from deep to shallow rupture during the East Cape earthquake. Therefore, the rupture evolution of the earthquake may have developed as discontinuous jumps by means of stress triggering (Miyazawa \& Mori, 2005; Sleep \& Ma, 2008; Fischer, Sammis, et al., 2008; Fischer, Peng, \& Sammis, 2008) across the apparent stress/strength barrier between the deep and shallow rupture areas. 
Large intraplate earthquakes within the downgoing plate in subduction zones are typically caused either by the down-dip bending and unbending of the slab (e.g., Astiz et al., 1988; Craig et al., 2014; Sandiford et al., 2020), the reactivation of major oceanic fabrics, including fracture zones (e.g., Abercrombie et al., 2003; Meng et al., 2012; Yue et al., 2012), or the tearing of the slab (e.g., Tanioka et al., 1995). However, the orientation and rupture complexity of the 2021 East Cape event deviates from these typical events. Two events with apparently similar deep trench-parallel compression in the slab include $2000 M_{\mathrm{W}} 7.9$ Enggano and $2009 M_{\mathrm{W}} 7.6$ Padang earthquakes, offshore Sumatra (Abercrombie et al., 2003; Wiseman et al., 2012). However, these events likely ruptured pre-existing fabrics in the downgoing plate (Abercrombie et al., 2003), such as fracture zones (Wiseman et al., 2012). Both earthquakes potentially represent the continuation of the diffuse deformation within the Wharton basin, and both consistently ruptured orthogonal fabrics toward the top of the downgoing plate both updip and downdip from the trench, where highly oblique convergence inherently causes a rotated state of the stress in the slab. In contrast, the 2021 East Cape earthquake, which occurred deeper beneath the top of the slab, does not align with the expected oceanic fabric, and is not obviously part of a wider, plate-scale, deformation field, where there is no obvious oblique convergence nor are fracture zones of an orientation consistent with the observed mechanisms subducted (Fig. 1). Instead, the rupture processes may represent a unique case, highlighting a different type of stress transition within the subducted slab.

\section{A contorted slab structure due to slab buoyancy variations?}

A key question is why does this part of the Hikurangi subduction zone exhibit an atypical stress regime, as manifested in the rupture process of the 2021 East Cape earthquake? Slab models of this region (Hayes, 2018; Hayes et al., 2018; Williams et al., 2013) show a homogeneous planar structure (Fig. S9) which would be expected to lead to a trench-normal compression in the deeper part of the slab. However, these slab models are poorly constrained near the East Cape earthquake, largely because of a lack of plate interface thrust earthquakes in the region (Fig. 1). The rupture process of the East Cape earthquake therefore potentially offers new insight into the local slab structure.

One possible explanation is that the slab surface warps downward north of the hypocenter, forming a depression at the plate interface (Fig. 4). The warping is likely a response to the buoyancy gradients in the subducting plate, which allows the less buoyant parts of the slab to sink more rapidly than the buoyant parts. The internal 
stress field from such a slab topology would be complex, leading to strong 3-D stress rotations around the localized downwarp in a manner as shown in the 2021 East Cape earthquake (Fig. 2). One contribution to the buoyancy gradients might be the subduction of a large-scale seamount. About $30 \mathrm{~km}$ south-west from the epicenter, the Quaternary Ruatoria seamount was obliquely subducted at the margin (Lewis et al., 1998; Collot et al., 2001; Lewis et al., 2004), forming the characteristic bathymetry of the Ruatoria indentation (Fig. 1). The Ruatoria seamount could deflect and bend the slab, causing the intraslab stress state to rotate from trench-normal compression to trench-parallel compression across the hypocentral area. Numerical models of slab stress in the presence of subducted buoyant features in the oceanic plate support such a stress rotation and lateral spreading mechanism (e.g., Mason et al., 2010). Trenchparallel compression has also been seen in other parts of the Hikurangi subduction zone, for example, Reyners and McGinty (1999) and McGinty et al. (2000) observed some strike-slip seismicity with a trench-parallel compression component, which are beneath or close to the shoreline of the Raukumara Peninsula. Although these earthquakes should reflect the stress state once the plate is already subducted, it is possible they reflect stress heterogeneity due to pervasive seamount subduction along the northern Hikurangi subduction zone (Barker et al., 2009).

An alternative explanation may arise from the location of the East Cape earthquake with respect to the transition between the Kermadec trench and Hikurangi margin, marked by the edge of the Hikurangi plateau, which is represented by a clear bathymetric scarp running along its northern boundary (Davy \& Collot, 2000). This transition from the subduction of normal oceanic lithosphere to the north, to the subduction of the thickened oceanic crust associated with the igneous Hikurangi plateau likely leads to a pronounced, short-wavelength flexural warping at the plateaus edge. The superposition of this N-S flexural stress field in conjunction with the down-dip bending stress field could have produced a complex pattern that varies at short-length scales within the subducted slab. Such a heterogeneous stress field may have regulated the rupture process of the East Cape earthquake. The sporadic background seismicity north of the 2021 source region (Fig. S16) might also result from such a complex stress field. It is noteworthy that in 2001, $\sim 80 \mathrm{~km}$ northeast of the 2021 event, there was a $M_{\mathrm{W}}$ 7.1 earthquake deep in the Pacific plate ( $\sim 60 \mathrm{~km}$ depth) showing a reverse faulting mechanism with its P-axis oriented perpendicular to the Kermadec trench (Fig. S8), which was likely driven by conventional trench-normal down-dip compression. This earthquake suggests that flexural warping due to the subducting Hikurangi plateau does not extend this far to the north. 


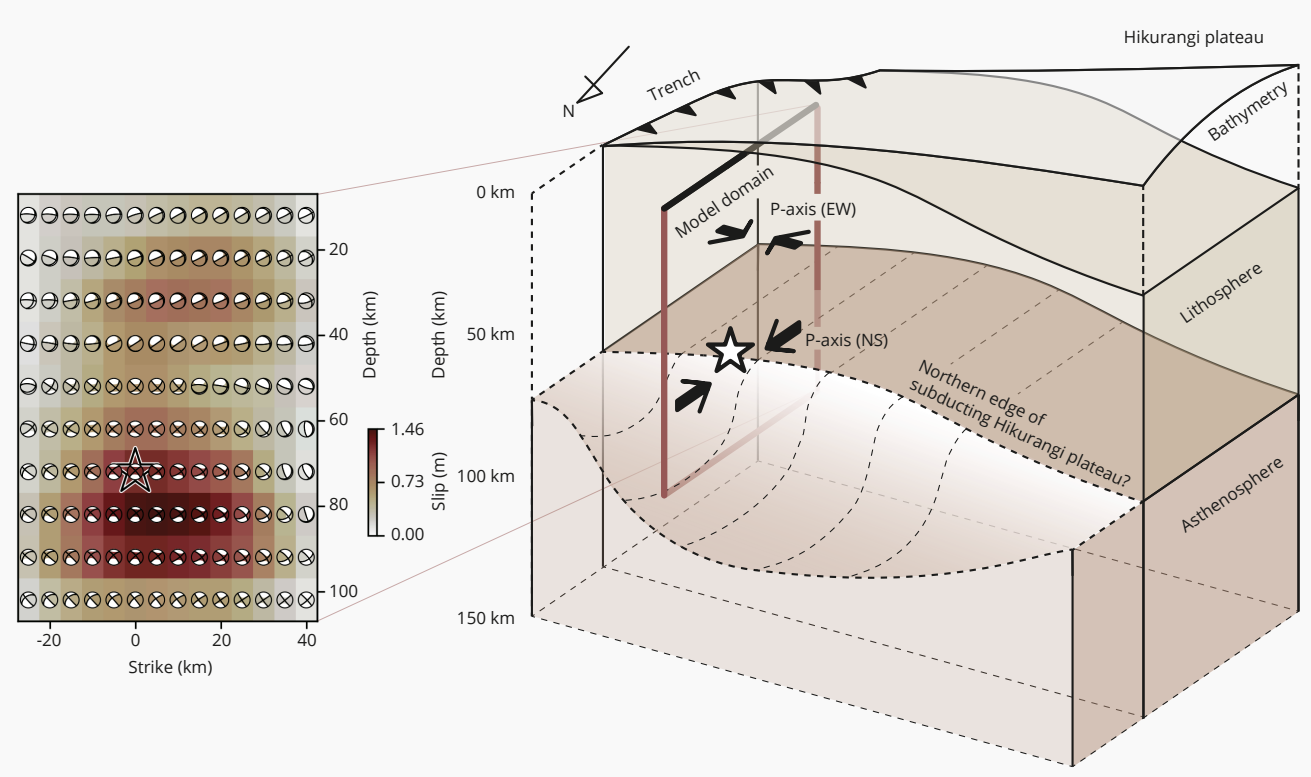

Figure 4. Cartoon interpretation of the inferred slab geometry and stress regimes based on our observations of the 2021 East Cape earthquake. The star shows the hypocenter. The arrow shows the compressional axis. The left panel shows the cross-section of our finite-fault solution (Fig. S7).

Whilst there have been many studies on the impact of subducting buoyant features on subduction megathrust coupling and interface seismogenesis (e.g., Wang \& Bilek, 2011; Nishikawa \& Ide, 2014), there have been far fewer studies that have considered their impact on intraslab seismicity. The rarity of deep intraslab earthquakes in the northern Hikurangi subduction zone makes it difficult to distinguish between the seamount and plateau models of stress rotation. However, it is also possible that both features play a concurrent role, with stress rotations superimposed from both. 


\section{Conclusions}

We determined the rupture geometry of the $2021 M_{\mathrm{W}} 7.3$ East Cape, New Zealand earthquake using a novel finite-fault inversion technique. Our method does not require a-priori knowledge of the fault geometry and can flexibly resolve complex faulting styles in large earthquakes. Therefore, it can illuminate the heterogeneous stress state near the earthquake. We show that the East Cape earthquake involves deep- and shallow-slip episodes, likely rupturing multiple faults with various faulting styles. We find distinct rupture episodes within the shallow $(\sim 30 \mathrm{~km})$ and deep $(\sim 70 \mathrm{~km})$ parts of the subducted oceanic plate, with distinct mechanisms of normal and a mixture of strike-slip and reverse faulting, respectively. The deep and shallow faulting episodes likely result from the superposition of depth-varying slab bending stress with more localized trench-parallel lateral variations in flexural stresses. The rotation of P-axes suggests that the intraplate stress state is locally rotated from trench-normal compression to trench-parallel compression. Such a stress rotation in depth requires the slab geometry to change sharply, which may have been induced by a subducted seamount or the additional buoyancy of the Hikurangi plateau. Our study suggests that understanding the generation of intermediate and deep intraslab seismicity requires a detailed treatment of localized variations in slab geometry caused by the subduction of heterogeneous features, such as ocean plateaus and seamounts. 


\section{Acknowledgments}

We thank editor Dr. Germán Prieto, associate editor Dr. Ake Fagereng, reviewers Dr. Emily Warren-Smith and Dr. Rachel Abercrombie, and anonymous reviewer for their evaluations and constructive suggestions. We thank Lingsen Meng, Han Bao, Baoning Wu, Richard G. Davy, Lior Suchoy, Fangqin Chen, Rhodri Davies, Tian Feng, Yuqing Xie, Liuwei Xu and Tong Zhou for the discussions. We are also grateful to John Ristau for discussions on the original GeoNet moment tensor solutions. TJC was supported in this work by the Royal Society under URF $\backslash \mathrm{R} 1 \backslash 180088$. COMET is the NERC Centre for the Observation and Modelling of Earthquakes, Volcanoes and Tectonics, a partnership between UK Universities and the British Geological Survey. This work was supported by the Grant-in-Aid for Scientific Research (C) 19K04030. The facilities of IRIS Data Services, and specifically the IRIS Data Management Center, were used for access to waveforms, related metadata, and/or derived products used in this study. IRIS Data Services are funded through the Seismological Facilities for the Advancement of Geoscience (SAGE) Award of the National Science Foundation under Cooperative Support Agreement EAR-1851048. We also thank the GeoNet data centre for making their continuous broadband and strong motion seismic data openly available. The authors declare no conflicts of interest relevant to this study.

\section{Open Research}

All the materials presented in this paper are archived and available at https://doi .org/10.5281/zenodo.5720036. All seismic data were downloaded through the IRIS Wilber 3 system (https://ds.iris.edu/wilber3/find_event) or IRIS Web Services (https://service.iris.edu), including the following seismic networks: the GT (Global Telemetered Seismograph Network (USAF/USGS); Albuquerque Seismological Laboratory (ASL)/USGS, 1993); the IC (New China Digital Seismograph Network; Albuquerque Seismological Laboratory (ASL)/USGS, 1992); the IU (Global Seismograph Network (GSN - IRIS/USGS); Albuquerque Seismological Laboratory (ASL)/USGS, 1988); the GE (GEOFON Seismic Network; GEOFON Data Centre, 1993); the AU (Australian National Seismograph Network (ANSN); Geoscience Australia (GA), 1994); the HK (Hong Kong Seismograph Network; Hong Kong Observatory, 2009); the G (GEOSCOPE; Institut De Physique Du Globe De Paris (IPGP) \& Ecole Et Observatoire Des Sciences De La Terre De Strasbourg (EOST), 1982); the NZ (New Zealand National Seismograph Network; Institute of Geological \& Nuclear Sciences Ltd (GNS New Zealand), 1988; Petersen et al., 2011); the AI (Antarctic Seismographic Argentinean Italian Network - OGS; Istituto Nazionale Di Oceanografia E Di Geofisica Sperimentale, 1992); the II 
(IRIS/IDA Seismic Network; Scripps Institution Of Oceanography, 1986); the C (Chilean National Seismic Network; Universidad de Chile Dept de Geofisica (DGF UChile Chile), 1991); the PS (Pacific21 (ERI/STA); University of Tokyo Earthquake Research Institute (Todai ERI Japan), 1989). We used ObsPy (Beyreuther et al., 2010, https://doi .org/10.5281/zenodo.165135), Pyrocko (The Pyrocko Developers, 2017, https:// pyrocko.org/), matplotlib (Hunter, 2007, https://doi.org/10.5281/zenodo.592536), Generic Mapping Tools (Wessel \& Luis, 2017, https://doi.org/10.5281/zenodo.3407865); and Scientific colour maps (Crameri, 2018; Crameri et al., 2020, https://doi .org/ 10.5281/zenodo.1243862) for data processing and visualisation. The NonLinLoc software used for hypocenter relocation is available at http://alomax. free. $\mathrm{fr} / \mathrm{nlloc} /$. The Grond software (Heimann et al., 2018) used for $W$-phase CMT inversion is available at https://pyrocko.org/grond/docs/current/. The ISOLA software used for R-CMT inversion is available at http://seismo.geology.upatras.gr/isola/.

\section{References}

Abercrombie, R. E., Antolik, M., \& Ekström, G. ～(2003). The June 2000 Mw 7.9 earthquakes south of Sumatra: Deformation in the India-Australia Plate . J. Geophys. Res. Solid Earth, 108(B1), 2018. doi:10.1029/2001jb000674

Akaike, H. (1980). $\quad$ Likelihood and the Bayes procedure. Trab. Estad. Y Investig. Oper., 31(1), 143-166. Retrieved from https://doi.org/10.1007/ BF02888350 doi:10.1007/BF02888350

Aki, K. (1979). Characterization of barriers on an earthquake fault. J. Geophys. Res., 84(B11), 6140. doi:10.1029/JB084iB11p06140

Albuquerque Seismological Laboratory (ASL)/USGS. (1988). Global Seismograph Network (GSN - IRIS/USGS). International Federation of Digital Seismograph Networks. doi:10.7914/SN/IU

Albuquerque Seismological Laboratory (ASL)/USGS. (1992). New China Digital Seismograph Network. International Federation of Digital Seismograph Networks. doi:10.7914/SN/IC

Albuquerque Seismological Laboratory (ASL)/USGS. (1993). Global Telemetered Seismograph Network (USAF/USGS). International Federation of Digital Seismograph Networks. Retrieved from http://www. fdsn.org/doi/10.7914/SN/GT doi:10.7914/SN/GT

Ammon, C. J., Kanamori, H., \& Lay, T. (2008). A great earthquake doublet and seismic stress transfer cycle in the central Kuril islands. Nature, 451(7178), 561565. doi:10.1038/nature 06521

Ampuero, J.-P., \& Dahlen, F. A. (2005). Ambiguity of the Moment Tensor. Bull. Seis- 
mol. Soc. Am., 95(2), 390-400. doi:10.1785/0120040103

Arai, R., Takahashi, T., Kodaira, S., Kaiho, Y., Nakanishi, A., Fujie, G., ... Kaneda, Y. (2016). Structure of the tsunamigenic plate boundary and low-frequency earthquakes in the southern Ryukyu Trench.

Nat. Commun., 7, 1-7. doi:10.1038/ncomms12255

Astiz, L., Lay, T., \& Kanamori, H. (1988). Large intermediate-depth earthquakes and the subduction process. Phys. Earth Planet. Inter., 53(1-2), 80-166. doi:10.1016/0031-9201(88)90138-0

Avouac, J. P., Ayoub, F., Wei, S., Ampuero, J. P., Meng, L., Leprince, S., ... Helmberger, D. (2014). The 2013, Mw 7.7 Balochistan earthquake, energetic strike-slip reactivation of a thrust fault. Earth Planet. Sci. Lett., 391, 128-134. doi:10.1016/j.epsl.2014.01.036

Barker, D. H., Sutherland, R., Henrys, S., \& Bannister, S. (2009). Geometry of the Hikurangi subduction thrust and upper plate, North Island, New Zealand. Geochemistry, Geophys. Geosystems, 10(2). doi:10.1029/2008GC002153

Bassett, D., Kopp, H., Sutherland, R., Henrys, S., Watts, A. B., Timm, C., ... Ronde, C. E. J. (2016). Crustal structure of the Kermadec arc from MANGO seismic refraction profiles. J. Geophys. Res. Solid Earth, 121(10), 7514-7546. doi:10.1002/2016JB013194

Bassett, D., Sutherland, R., Henrys, S., Stern, T., Scherwath, M., Benson, A., ... Henderson, M. (2010). Three-dimensional velocity structure of the northern Hikurangi margin, Raukumara, New Zealand: Implications for the growth of continental crust by subduction erosion and tectonic underplating. Geochemistry, Geophys. Geosystems, 11(10). doi:10.1029/2010GC003137

Bell, R., Sutherland, R., Barker, D. H., Henrys, S., Bannister, S., Wallace, L., \& Beavan, J. (2010). Seismic reflection character of the Hikurangi subduction interface, New Zealand, in the region of repeated Gisborne slow slip events. Geophys. J. Int., 180(1), 34-48. doi:10.1111/j.1365-246X.2009.04401.x

Beyreuther, M., Barsch, R., Krischer, L., Megies, T., Behr, Y., \& Wassermann, J. (2010). ObsPy: A Python Toolbox for Seismology. Seismol. Res. Lett., 81(3), 530-533. doi:10.1785/gssrl.81.3.530

Bird, P. (2003). An updated digital model of plate boundaries. Geochemistry, Geophys. Geosystems, 4(3), 1105. doi:10.1029/2001GC000252

Bormann, P. (2012). New Manual of Seismological Observatory Practice (NMSOP-2). IASPEI, GFZ Ger. Res. Cent. Geosci.. doi:10.2312/GFZ.NMSOP-2

Collot, J. Y., Delteil, J., Lewis, K. B., Davy, B., Lamarche, G., Audru, J. C., ... Uruski, C. (1996). From oblique subduction to intra-continental transpression: 
Structures of the southern Kermadec-Hikurangi margin from multibeam bathymetry, side-scan sonar and seismic reflection. Mar. Geophys. Res., 18(2-4), 357-381. doi:10.1007/BF00286085

Collot, J. Y., Lewis, K., Lamarche, G., \& Lallemand, S. (2001). The giant Ruatoria debris avalanche on the northern Hikurangi margin, New Zealand: Result of oblique seamount subduction. J. Geophys. Res. Solid Earth, 106(B9), 1927119297. doi:10.1029/2001jb900004

Craig, T. J., Copley, A., \& Jackson, J. (2014). A reassessment of outer-rise seismicity and its implications for the mechanics of oceanic lithosphere. Geophys. J. Int., 197(1), 63-89. doi:10.1093/gji/ggu013

Crameri, F. (2018). Geodynamic diagnostics, scientific visualisation and StagLab 3.0. Geosci. Model Dev., 11(6), 2541-2562. doi:10.5194/gmd-11-2541-2018

Crameri, F., Shephard, G. E., \& Heron, P. J. (2020). The misuse of colour in science communication. Nat. Commun., 11(1), 5444. doi:10.1038/s41467-020-191607

Das, S., \& Aki, K. (1977). Fault plane with barriers: A versatile earthquake model. J. Geophys. Res., 82(36), 5658-5670. doi:10.1029/JB082i036p05658

Dascher-Cousineau, K., Brodsky, E. E., Lay, T., \& Goebel, T. H. W. (2020). What Controls Variations in Aftershock Productivity? J. Geophys. Res. Solid Earth, 125(2), e2019JB018111. doi:10.1029/2019JB018111

Davey, F. J., Henrys, S., \& Lodolo, E. (1997). A seismic crustal section across the East Cape convergent margin, New Zealand. Tectonophysics, 269(3-4), 199-215. doi:10.1016/S0040-1951(96)00165-5

Davy, B., \& Collot, J. Y. (2000). The Rapuhia Scarp (northern Hikurangi Plateau) - Its nature and subduction effects on the Kermadec Trench. Tectonophysics, 328(3-4), 269-295. doi:10.1016/S0040-1951(00)00211-0

DeMets, C., Gordon, R. G., \& Argus, D. F. ～(2010). Geologically current plate motions. Geophys. J. Int., 181(1), 1-80. doi:10.1111/j.1365-246X.2009.04491.x

Duputel, Z., Agram, P. S., Simons, M., Minson, S. E., \& Beck, J. L. (2014). Accounting for prediction uncertainty when inferring subsurface fault slip. Geophys. J. Int., 197(1), 464-482. doi:10.1093/gji/ggt517

Duputel, Z., Rivera, L., Kanamori, H., \& Hayes, G. (2012). W phase source inversion for moderate to large earthquakes (1990-2010). Geophys. J. Int., 189(2), 11251147. doi:10.1111/j.1365-246X.2012.05419.x

Duputel, Z., Tsai, V. C., Rivera, L., \& Kanamori, H. (2013). Using centroid time-delays to characterize source durations and identify earthquakes with unique characteristics. Earth Planet. Sci. Lett., 374, 92-100.

Re- 
trieved from http://dx.doi.org/10.1016/j.epsl.2013.05.024

doi:10.1016/j.epsl.2013.05.024

Dziewonski, A. M., Chou, T.-A., \& Woodhouse, J. H. ～(1981). Determination of earthquake source parameters from waveform data for studies of global and regional seismicity. J. Geophys. Res. Solid Earth, 86(B4), 2825-2852. doi:10.1029/JB086iB04p02825

Eberhart-Phillips, D., Bannister, S., Reyners, M., \& Henrys, S. (2020). New Zealand Wide model 2.2 seismic velocity and Qs and Qp models for New Zealand. Zenodo. doi:10.5281/zenodo.3779523

Eberhart-Phillips, D., \& Reyners, M. (1999). Plate interface properties in the northeast Hikurangi subduction zone, New Zealand, from converted seismic waves. Geophys. Res. Lett., 26(16), 2565-2568. doi:10.1029/1999GL900567

Eberhart-Phillips, D., Reyners, M., Bannister, S., Chadwick, M., \& Ellis, S. $\quad$ (2010). Establishing a versatile 3-D seismic velocity model for New Zealand. Seismol. Res. Lett., 81(6), 992-1000. doi:10.1785/gssrl.81.6.992

Ekström, G., Nettles, M., \& Dziewoński, A. (2012). The global CMT project 2004-2010: Centroid-moment tensors for 13,017 earthquakes. Phys. Earth Planet. Inter., 200-201, 1-9. doi:10.1016/j.pepi.2012.04.002

Elliott, J. R., Jolivet, R., Gonzalez, P. J., Avouac, J. P., Hollingsworth, J., Searle, M. P., \& Stevens, V. L. (2016). Himalayan megathrust geometry and relation to topography revealed by the Gorkha earthquake. Nat. Geosci., 9(2), 174-180. doi:10.1038/ngeo2623

Fischer, A. D., Peng, Z., \& Sammis, C. G. $\quad$ (2008). Dynamic triggering of highfrequency bursts by strong motions during the 2004 Parkfield earthquake sequence. Geophys. Res. Lett., 35(12), L12305. doi:10.1029/2008GL033905

Fischer, A. D., Sammis, C. G., Chen, Y., \& Teng, T.-L. (2008). Dynamic Triggering by Strong-Motion P and S Waves: Evidence from the 1999 Chi-Chi, Taiwan, Earthquake.

Bull. Seismol. Soc. Am., 98(2), 580-592. doi:10.1785/0120070155

Floyd, M. A., Walters, R. J., Elliott, J. R., Funning, G. J., Svarc, J. L., Murray, J. R., ... Wright, T. J. (2016). Spatial variations in fault friction related to lithology from rupture and afterslip of the 2014 South Napa, California, earthquake. Geophys. Res. Lett., 43(13), 6808-6816. doi:10.1002/2016GL069428

Fukuda, J., \& Johnson, K. M. (2008). A fully Bayesian inversion for spatial distribution of fault slip with objective smoothing. Bull. Seismol. Soc. Am., 98(3), 11281146. doi:10.1785/0120070194

GEOFON Data Centre. (1993). GEOFON Seismic Network. Deutsches Geo- 
ForschungsZentrum GFZ. doi:10.14470/TR560404

GeoNet. (2021). GeoNet Earthquake Catalog. Retrieved from https://www. geonet .org.nz/data/types/eq_catalogue

GeoNet Moment Tensors. (2021). GeoNet Moment Tensors. Retrieved from https:// github.com/GeoNet/data/tree/main/moment-tensor

GeoNet News. (2021). Friday 5 March Tsunami: What happened and what did you see? Retrieved from https://www.geonet.org.nz/news/ 1gvqVOoHGIULbydSQD8W1Y

Geoscience Australia (GA). (1994). Australian National Seismograph Network (ANSN). Retrieved from https://www.fdsn.org/networks/detail/AU/

Gomberg, J., \& Bodin, P. (2021). The Productivity of Cascadia Aftershock Sequences. Bull. Seismol. Soc. Am., 111(3), 1-14. doi:10.1785/0120200344

Hamling, I. J., Hreinsdóttir, S., Clark, K., Elliott, J., Liang, C., Fielding, E., ... Stirling, M. (2017). Complex multifault rupture during the 2016 Mw 7.8 Kaikōura earthquake, New Zealand. Science, 356(6334). doi:10.1126/science.aam7194

Hayes, G. P. (2018). Slab2 - A Comprehensive Subduction Zone Geometry Model: U.S. Geological Survey data release. doi:10.5066/F7PV6JNV

Hayes, G. P., Moore, G. L., Portner, D. E., Hearne, M., Flamme, H., Furtney, M., \& Smoczyk, G. M. (2018). Slab2, a comprehensive subduction zone geometry model. Science, 362(6410), 58-61. doi:10.1126/science.aat4723

Heimann, S., Isken, M., Kühn, D., Sudhaus, H., Steinberg, A., Vasyura-Bathke, H.,... Dahm, T. (2018). Grond - A probabilistic earthquake source inversion framework. Retrieved from http://pyrocko.org/grond/docs/current/ doi:10.5880/GFZ.2.1.2018.003

Henrys, S., Reyners, M., Pecher, I., Bannister, S., Nishimura, Y., \& Maslen, G. (2006). Kinking of the subducting slab by escalator normal faulting beneath the North Island of New Zealand. Geology, 34(9), 777-780. doi:10.1130/G22594.1

Hicks, S. P., Okuwaki, R., Steinberg, A., Rychert, C. A., Harmon, N., Abercrombie, R. E., ... Sudhaus, H. (2020). Back-propagating supershear rupture in the $2016 \mathrm{Mw} 7.1$ Romanche transform fault earthquake. Nat. Geosci., 13(9), 647-653. doi:10.1038/s41561-020-0619-9

Hicks, S. P., \& Rietbrock, A. (2015). Seismic slip on an upper-plate normal fault during a large subduction megathrust rupture. $\quad$ Nat. Geosci., 8(12), 955-960. doi:10.1038/ngeo 2585

Hong Kong Observatory. (2009). Hong Kong Seismograph Network. Retrieved from http://www.hko.gov.hk/gts/equake/sp_seismo_network_intro_e.htm

Hunter, J. D. (2007). Matplotlib: A 2D Graphics Environment. Comput. Sci. Eng., 
9(3), 90-95. doi:10.1109/MCSE.2007.55

Institut De Physique Du Globe De Paris (IPGP), \& Ecole Et Observatoire Des Sciences De La Terre De Strasbourg (EOST). (1982). GEOSCOPE, French Global Network of broad band seismic stations. Institut de physique du globe de Paris (IPGP), Université de Paris. doi:10.18715/GEOSCOPE.G

Institute of Geological \& Nuclear Sciences Ltd (GNS New Zealand).

(1988). New Zealand National Seismograph Network.

Retrieved from https:// www.fdsn.org/networks/detail/NZ/

International Seismological Centre. (2021).

On-line Bulletin. doi:10.31905/D808B830

Istituto Nazionale Di Oceanografia E Di Geofisica Sperimentale. (1992). Antarctic Seismographic Argentinean Italian Network - OGS. International Federation of Digital Seismograph Networks. doi:10.7914/SN/AI

Kaneko, Y., Ito, Y., Chow, B., Wallace, L. M., Tape, C., Grapenthin, R., ... Hino, R. (2019). Ultra-long Duration of Seismic Ground Motion Arising From a Thick, Low-Velocity Sedimentary Wedge. J. Geophys. Res. Solid Earth, 124(10), 1034710359. doi:10.1029/2019JB017795

Kennett, B. L., Engdahl, E. R., \& Buland, R. (1995). Constraints on seismic velocities in the Earth from traveltimes. Geophys. J. Int., 122(1), 108-124. doi:10.1111/j.1365-246X.1995.tb03540.x

Kikuchi, M., \& Kanamori, H. (1991). Inversion of complex body wavesIII. Bull. Seism. Soc. Am., 81(6), 2335-2350. Retrieved from https:// pubs.geoscienceworld.org/ssa/bssa/article-abstract/81/6/2335/ 102472/Inversion-of-complex-body-waves-III

Laske, G., Masters, T. G., Ma, Z., \& Pasyanos, M. (2013). Update on CRUST1.0 - A 1degree Global Model of Earth's Crust. Geophys. Res. Abstr. 15, Abstr. EGU20132658, 15, Abstract EGU2013-2658. Retrieved from https://igppweb.ucsd .edu/ gabi/crust1.html

Lay, T., Duputel, Z., Ye, L., \& Kanamori, H. (2013). The December 7, 2012 Japan Trench intraplate doublet ( $\mathrm{Mw} 7.2,7.1)$ and interactions between near-trench intraplate thrust and normal faulting. Phys. Earth Planet. Inter., 220, 73-78. doi:10.1016/j.pepi.2013.04.009

Lay, T., Ye, L., Wu, Z., \& Kanamori, H. (2020). Macrofracturing of Oceanic Lithosphere in Complex Large Earthquake Sequences. J. Geophys. Res. Solid Earth, 125(10), 1-21. doi:10.1029/2020JB020137

Lewis, K. B., Collot, J. Y., \& Lallemand, S. E. $\quad$ (1998). The dammed Hikurangi Trough: A channel-fed trench blocked by subducting seamounts and their 
wake avalanches (New Zealand-France GeodyNZ Project). Basin Res., 10(4), 441-468. doi:10.1046/j.1365-2117.1998.00080.x

Lewis, K. B., Lallemand, S. E., \& Carter, L. (2004). Collapse in a quaternary shelf basin off East Cape, New Zealand: Evidence for passage of a subducted seamount inboard of the ruatoria giant avalanche. New Zeal. J. Geol. Geophys., 47(3), 415-429. doi:10.1080/00288306.2004.9515067

Lomax, A., Michelini, A., \& Curtis, A. (2009). Earthquake Location, Direct, GlobalSearch Methods BT - Encyclopedia of Complexity and Systems Science. Encycl. Complex. Syst. Sci., 2449-2473. doi:10.1007/978-0-387-30440-3_150

Lomax, A., Virieux, J., Volant, P., \& Berge-Thierry, C. (2000). Probabilistic Earthquake Location in 3D and Layered Models BT - Advances in Seismic Event Location. In C. H. Thurber \& N. Rabinowitz (Eds.), (pp. 101-134). Dordrecht: Springer Netherlands. doi:10.1007/978-94-015-9536-0_5

Mason, W. G., Moresi, L., Betts, P. G., \& Miller, M. S. (2010). Three-dimensional numerical models of the influence of a buoyant oceanic plateau on subduction zones. Tectonophysics, 483(1-2), 71-79. doi:10.1016/j.tecto.2009.08.021

McGinty, P., Reyners, M., \& Robinson, R. (2000). Stress directions in the shallow part of the Hikurangi subduction zone, New Zealand, from the inversion of earthquake first motions. Geophys. J. Int., 142(2), 339-350. doi:10.1046/j.1365-246X.2000.00155.x

Meng, L., Ampuero, J. P., Stock, J., Duputel, Z., Luo, Y., \& Tsai, V. C. Earthquake in a maze: Compressional rupture branching during the $2012 \mathrm{Mw}$ 8.6 Sumatra earthquake. Science, 337(6095), 724-726. doi:10.1126/science.1224030

Minson, S. E., Simons, M., \& Beck, J. L. (2013). Bayesian inversion for finite fault earthquake source models I-theory and algorithm. Geophys. J. Int., 194(3), 1701-1726. doi:10.1093/gji/ggt180

Mitchell, J. S., Mackay, K. A., Neil, H. L., Mackay, E. J., Pallentin, A., \& Notman, P. (2012). Undersea New Zealand, 1: 5,000,000. NIWA chart, Misc. Ser., 92. Retrieved from https://niwa.co.nz/our-science/oceans/bathymetry/ further-information

Miyazawa, M., \& Mori, J. (2005). Detection of triggered deep low-frequency events from the 2003 Tokachi-oki earthquake. Geophys. Res. Lett., 32(10), 1-4. doi:10.1029/2005GL022539

Mochizuki, K., Henrys, S., Haijima, D., Warren-Smith, E., \& Fry, B. (2021). Seismicity and velocity structure in the vicinity of repeating slow slip earthquakes, northern Hikurangi subduction zone, New Zealand. $\quad$ Earth Planet. 
Sci. Lett., 563, 116887.

Retrieved from https://doi.org/10.1016/ j.epsl.2021.116887 doi:10.1016/j.epsl.2021.116887

Nishikawa, T., \& Ide, S. (2014). Earthquake size distribution in subduction zones linked to slab buoyancy. Nat. Geosci., 7(12), 904-908. doi:10.1038/ngeo2279

Ohta, Y., Miura, S., Ohzono, M., Kita, S., Linuma, T., Demachi, T., ... Umino, N. (2011). Large intraslab earthquake (2011 April 7, M 7.1) after the 2011 off the Pacific coast of Tohoku Earthquake (M 9.0): Coseismic fault model based on the dense GPS network data. Earth, Planets Sp., 63(12), 1207-1211. doi:10.5047/eps.2011.07.016

Okada, T., \& Hasegawa, A. (2003). The M7.1 May 26, 2003 off-shore Miyagi Prefecture Earthquake in northeast Japan: Source process and aftershock distribution of an intra-slab event. $\quad$ Earth, Planets Sp., 55(12), 731-739. doi:10.1186/BF03352482

Okuwaki, R., Hirano, S., Yagi, Y., \& Shimizu, K. （2020). Inchworm-like source evolution through a geometrically complex fault fueled persistent supershear rupture during the 2018 Palu Indonesia earthquake. Earth Planet. Sci. Lett., 547, 116449. doi:10.1016/j.epsl.2020.116449

Okuwaki, R., Yagi, Y., Aránguiz, R., González, J., \& González, G. (2016). Rupture Process During the 2015 Illapel, Chile Earthquake: Zigzag-Along-Dip Rupture Episodes. Pure Appl. Geophys., 173(4), 1011-1020. doi:10.1007/s00024-0161271-6

Page, M. T., van Der Elst, N., Hardebeck, J., Felzer, K., \& Michael, A. J.

(2016). Three ingredients for improved global aftershock forecasts: Tectonic region, time-dependent catalog incompleteness, and intersequence variability. Bull. Seismol. Soc. Am., 106(5), 2290-2301. doi:10.1785/0120160073

Petersen, T., Gledhill, K., Chadwick, M., Gale, N. H., \& Ristau, J. (2011). The New Zealand National Seismograph Network. Seismol. Res. Lett., 82(1), 9-20. doi:10.1785/gssrl.82.1.9

Ragon, T., Sladen, A., \& Simons, M. (2018). Accounting for uncertain fault geometry in earthquake source inversions - I: theory and simplified application. Geophys. J. Int., 214(2), 1174-1190. Retrieved from https://doi .org/10.1093/ gji/ggy187 doi:10.1093/gji/ggy187

Ranero, C. R., Villaseñor, A., Morgan, J. P., \& Weinrebe, W. (2005). Relationship between bend-faulting at trenches and intermediate-depth seismicity. Geochemistry, Geophys. Geosystems, 6(12). doi:10.1029/2005GC000997

Reyners, M., Eberhart-Phillips, D., Stuart, G., \& Nishimura, Y. (2006). Imaging subduction from the trench to $300 \mathrm{~km}$ depth beneath the central North Is- 
land, New Zealand, with Vp and Vp/Vs. Geophys. J. Int., 165(2), 565-583. doi:10.1111/j.1365-246X.2006.02897.x

Reyners, M., \& McGinty, P. (1999). Shallow subduction tectonics in the Raukumara Peninsula, New Zealand, as illuminated by earthquake focal mechanisms. $\quad J$. Geophys. Res. Solid Earth, 104(B2), 3025-3034. doi:10.1029/1998JB900081

Romeo, I., \& Álvarez-Gómez, J. A. (2018). Lithospheric folding by flexural slip in subduction zones as source for reverse fault intraslab earthquakes. Sci. Rep., 8(1), 1-9. doi:10.1038/s41598-018-19682-7

Sandiford, D., Moresi, L., Sandiford, M., \& Yang, T. ～(2019). Geometric controls on flat slab seismicity. $\quad$ Earth Planet. Sci. Lett., 527, 115787. doi:10.1016/j.epsl.2019.115787

Sandiford, D., Moresi, L. M., Sandiford, M., Farrington, R., \& Yang, T.

(2020). The Fingerprints of Flexure in Slab Seismicity.

Tectonics, 39(8). doi:10.1029/2019TC005894

Scripps Institution Of Oceanography. (1986). IRIS/IDA Seismic Network. International Federation of Digital Seismograph Networks. doi:10.7914/SN/II

Shimizu, K., Yagi, Y., Okuwaki, R., \& Fukahata, Y. (2020). Development of an inversion method to extract information on fault geometry from teleseismic data. Geophys. J. Int., 220(2), 1055-1065. doi:10.1093/gji/ggz496

Shimizu, K., Yagi, Y., Okuwaki, R., \& Fukahata, Y. (2021). Construction of fault geometry by finite-fault inversion of teleseismic data. Geophys. J. Int., 224(2), 1003-1014. doi:10.1093/gji/ggaa501

Simons, M., Fialko, Y., \& Rivera, L. (2002). Coseismic deformation from the $1999 \mathrm{Mw}$ 7.1 Hector Mine, California, earthquake as inferred from InSAR and GPS observations. Bull. Seismol. Soc. Am., 92(4), 1390-1402. doi:10.1785/0120000933

Sippl, C., Schurr, B., Asch, G., \& Kummerow, J. $\quad$ (2018). Seismicity Structure of the Northern Chile Forearc From $>100,000$ Double-Difference Relocated Hypocenters. J. Geophys. Res. Solid Earth, 123(5), 4063-4087. doi:10.1002/2017JB015384

Sleep, N. H., \& Ma, S. (2008). Production of brief extreme ground acceleration pulses by nonlinear mechanisms in the shallow subsurface. Geochemistry, Geophys. Geosystems, 9(3), Q03008. doi:10.1029/2007GC001863

Sokos, E. N., \& Zahradnik, J. (2008). ISOLA a Fortran code and a Matlab GUI to perform multiple-point source inversion of seismic data. Comput. Geosci., 34(8), 967-977. doi:10.1016/j.cageo.2007.07.005

Tadapansawut, T., Okuwaki, R., Yagi, Y., \& Yamashita, S. (2021). Rupture Process of 
the 2020 Caribbean Earthquake Along the Oriente Transform Fault, Involving Supershear Rupture and Geometric Complexity of Fault. Geophys. Res. Lett., 48(1), 1-9. doi:10.1029/2020GL090899

Tanioka, Y., Ruff, L., \& Satake, K. (1995). The great Kurile Earthquake of October 4, 1994 tore the slab. Geophys. Res. Lett., 22(13), 1661-1664. doi:10.1029/95GL01656

The Pyrocko Developers. (2017). Pyrocko: A Versatile Seismology Toolkit for Python. Retrieved from http://pyrocko.org doi:10.5880/GFZ.2.1.2017.001

Todd, E. K., \& Lay, T. (2013). The 2011 Northern Kermadec earthquake doublet and subduction zone faulting interactions. J. Geophys. Res. Solid Earth, 118(1), 249261. doi:10.1029/2012JB009711

Universidad de Chile Dept de Geofisica (DGF UChile Chile). (1991). Chilean National Seismic Network. Retrieved from https://www.fdsn.org/networks/ $\operatorname{detail/C/}$

University of Tokyo Earthquake Research Institute (Todai ERI Japan).

(1989). Pacific21 (ERI/STA). Retrieved from https://www.fdsn.org/networks/ detail/PS/

U.S. Geological Survey Earthquake Hazards Program. (2017). Advanced National Seismic System (ANSS) Comprehensive Catalog of Earthquake Events and Products. doi:10.5066/F7MS3QZH

Vallée, M. (2013). Source time function properties indicate a strain drop independent of earthquake depth and magnitude. Nat. Commun., 4, 1-6. doi:10.1038/ncomms3606

Vallée, M., Charléty, J., Ferreira, A. M., Delouis, B., \& Vergoz, J. (2011). SCARDEC: A new technique for the rapid determination of seismic moment magnitude, focal mechanism and source time functions for large earthquakes using bodywave deconvolution. Geophys. J. Int., 184(1), 338-358. doi:10.1111/j.1365246X.2010.04836.x

Wallace, L. M., Reyners, M., Cochran, U., Bannister, S., Barnes, P. M., Berryman, K., ... Power, W. (2009). Characterizing the seismogenic zone of a major plate boundary subduction thrust: Hikurangi Margin, New Zealand. Geochemistry, Geophys. Geosystems, 10(10). doi:10.1029/2009GC002610

Wang, K., \& Bilek, S. L. (2011). Do subducting seamounts generate or stop large earthquakes? Geology, 39(9), 819-822. doi:10.1130/G31856.1

Wessel, P., \& Luis, J. F. (2017). The GMT/MATLAB Toolbox. Geochemistry, Geophys. Geosystems, 18(2), 811-823. doi:10.1002/2016GC006723

Wiens, D. A. (2001). Seismological constraints on the mechanism of deep earth- 
quakes: Temperature dependence of deep earthquake source properties. Phys. Earth Planet. Inter., 127(1-4), 145-163. doi:10.1016/S0031-9201(01)00225-4

Williams, C. A., Eberhart-Phillips, D., Bannister, S., Barker, D. H., Henrys, S., Reyners, M., \& Sutherland, R. (2013). Revised interface geometry for the hikurangi subduction zone, New Zealand. $\quad$ Seismol. Res. Lett., 84(6), 1066-1073. doi:10.1785/0220130035

Wiseman, K., Banerjee, P., Bürgmann, R., Sieh, K., Dreger, D. S., \& Hermawan, I. (2012). Source model of the $2009 \mathrm{Mw} 7.6$ Padang intraslab earthquake and its effect on the Sunda megathrust. Geophys. J. Int., 190(3), 1710-1722. doi:10.1111/j.1365-246X.2012.05600.x

Yabuki, T., \& Matsu'ura, M. (1992). Geodetic data inversion using a Bayesian information criterion for spatial distribution of fault slip. Geophys. J. Int., 109(2), 363-375. Retrieved from https://onlinelibrary.wiley.com/doi/abs/ $10.1111 / j .1365-246 X .1992$.tb00102.xhttps: //academic.oup.com/ gji/article-lookup/doi/10.1111/j.1365-246X.1992.tb00102.x doi:10.1111/j.1365-246X.1992.tb00102.x

Yagi, Y., \& Fukahata, Y. (2011). Introduction of uncertainty of Green's function into waveform inversion for seismic source processes. Geophys. J. Int., 186(2), 711720. doi:10.1111/j.1365-246X.2011.05043.x

Yamashita, S., Yagi, Y., Okuwaki, R., Shimizu, K., Agata, R., \& Fukahata, Y. (2021). Consecutive ruptures on a complex conjugate fault system during the 2018 Gulf of Alaska earthquake. Sci. Rep., 11(1), 5979. doi:10.1038/s41598-02185522-w

Ye, L., Lay, T., Bai, Y., Cheung, K. F., \& Kanamori, H. ～(2017). The 2017 Mw 8.2 Chiapas, Mexico, Earthquake: Energetic Slab Detachment. Geophys. Res. Lett., 44(23), 11,824-11,832. doi:10.1002/2017GL076085

Ye, L., Lay, T., \& Kanamori, H. (2012). Intraplate and interplate faulting interactions during the August 31, 2012, Philippine Trench earthquake (Mw 7.6) sequence. Geophys. Res. Lett., 39(24), 1-6. doi:10.1029/2012GL054164

Ye, L., Lay, T., \& Kanamori, H. (2021). The 25 March 2020 Mw 7.5 Paramushir, northern Kuril Islands earthquake and major $(\mathrm{Mw} \geq 7.0)$ near-trench intraplate compressional faulting. Earth Planet. Sci. Lett., 556(March 2020), 116728. doi:10.1016/j.epsl.2020.116728

Yue, H., Lay, T., \& Koper, K. D. (2012). En échelon and orthogonal fault ruptures of the 11 April 2012 great intraplate earthquakes. Nature, 490(7419), 245-249. doi:10.1038/nature11492 


\section{References From the Supporting Information}

Ampuero, J.-P., \& Dahlen, F. A. (2005). Ambiguity of the Moment Tensor. Bull. Seismol. Soc. Am., 95(2), 390-400. doi:10.1785/0120040103

Bassett, D., Sutherland, R., Henrys, S., Stern, T., Scherwath, M., Benson, A., ... Henderson, M. (2010). Three-dimensional velocity structure of the northern Hikurangi margin, Raukumara, New Zealand: Implications for the growth of continental crust by subduction erosion and tectonic underplating. Geochemistry, Geophys. Geosystems, 11(10). doi:10.1029/2010GC003137

Bird, P. (2003). An updated digital model of plate boundaries. Geochemistry, Geophys. Geosystems, 4(3), 1105. doi:10.1029/2001GC000252

Bormann, P. (2012). New Manual of Seismological Observatory Practice (NMSOP-2). IASPEI, GFZ Ger. Res. Cent. Geosci.. doi:10.2312/GFZ.NMSOP-2

Duputel, Z., Rivera, L., Kanamori, H., \& Hayes, G. (2012). W phase source inversion for moderate to large earthquakes (1990-2010). Geophys. J. Int., 189(2), 11251147. doi:10.1111/j.1365-246X.2012.05419.x

Dziewonski, A. M., Chou, T.-A., \& Woodhouse, J. H. $\quad$ (1981). Determination of earthquake source parameters from waveform data for studies of global and regional seismicity. J. Geophys. Res. Solid Earth, 86(B4), 2825-2852. doi:10.1029/JB086iB04p02825

Eberhart-Phillips, D., Bannister, S., Reyners, M., \& Henrys, S. (2020). New Zealand Wide model 2.2 seismic velocity and Qs and Qp models for New Zealand. Zenodo. doi:10.5281/zenodo.3779523

Eberhart-Phillips, D., Reyners, M., Bannister, S., Chadwick, M., \& Ellis, S. (2010). Establishing a versatile 3-D seismic velocity model for New Zealand. Seismol. Res. Lett., 81(6), 992-1000. doi:10.1785/gssrl.81.6.992

Ekström, G., Nettles, M., \& Dziewoński, A. (2012). The global CMT project 2004-2010: Centroid-moment tensors for 13,017 earthquakes. Phys. Earth Planet. Inter., 200-201, 1-9. doi:10.1016/j.pepi.2012.04.002

GeoNet. (2021). GeoNet Earthquake Catalog. Retrieved from https://www. geonet .org.nz/data/types/eq_catalogue

GeoNet Moment Tensors. (2021). GeoNet Moment Tensors. Retrieved from https:// github.com/GeoNet/data/tree/main/moment-tensor

Hayes, G. P. (2018). Slab2 - A Comprehensive Subduction Zone Geometry Model: U.S. Geological Survey data release. doi:10.5066/F7PV6JNV

Hayes, G. P., Moore, G. L., Portner, D. E., Hearne, M., Flamme, H., Furtney, M., \& Smoczyk, G. M. (2018). Slab2, a comprehensive subduction zone geometry model. Science, 362(6410), 58-61. doi:10.1126/science.aat4723 
Heimann, S., Isken, M., Kühn, D., Sudhaus, H., Steinberg, A., Vasyura-Bathke, H.,... Dahm, T. (2018). Grond-A probabilistic earthquake source inversion framework. Retrieved from http://pyrocko.org/grond/docs/current/ doi:10.5880/GFZ.2.1.2018.003

Kennett, B. L., Engdahl, E. R., \& Buland, R. $\quad$ (1995). Constraints on seismic velocities in the Earth from traveltimes. Geophys. J. Int., 122(1), 108-124. doi:10.1111/j.1365-246X.1995.tb03540.x

Kikuchi, M., \& Kanamori, H. (1991). Inversion of complex body wavesIII. Bull. Seism. Soc. Am., 81(6), 2335-2350. Retrieved from https:// pubs.geoscienceworld.org/ssa/bssa/article-abstract/81/6/2335/ 102472/Inversion-of-complex-body-waves-III

Laske, G., Masters, T. G., Ma, Z., \& Pasyanos, M. (2013). Update on CRUST1.0 - A 1degree Global Model of Earth's Crust. Geophys. Res. Abstr. 15, Abstr. EGU20132658, 15, Abstract EGU2013-2658. Retrieved from https://igppweb.ucsd .edu/ gabi/crust1.html

Lomax, A., Michelini, A., \& Curtis, A. (2009). Earthquake Location, Direct, GlobalSearch Methods BT - Encyclopedia of Complexity and Systems Science. Encycl. Complex. Syst. Sci., 2449-2473. doi:10.1007/978-0-387-30440-3_150

Lomax, A., Virieux, J., Volant, P., \& Berge-Thierry, C. (2000). Probabilistic Earthquake Location in 3D and Layered Models BT - Advances in Seismic Event Location. In C. H. Thurber \& N. Rabinowitz (Eds.), (pp. 101-134). Dordrecht: Springer Netherlands. doi:10.1007/978-94-015-9536-0_5

Okuwaki, R., Hirano, S., Yagi, Y., \& Shimizu, K. (2020). Inchworm-like source evolution through a geometrically complex fault fueled persistent supershear rupture during the 2018 Palu Indonesia earthquake. Earth Planet. Sci. Lett., 547, 116449. doi:10.1016/j.epsl.2020.116449

Okuwaki, R., Yagi, Y., Aránguiz, R., González, J., \& González, G. (2016). Rupture Process During the 2015 Illapel, Chile Earthquake: Zigzag-Along-Dip Rupture Episodes. Pure Appl. Geophys., 173(4), 1011-1020. doi:10.1007/s00024-016$1271-6$

Petersen, T., Gledhill, K., Chadwick, M., Gale, N. H., \& Ristau, J. (2011). The New Zealand National Seismograph Network. Seismol. Res. Lett., 82(1), 9-20. doi:10.1785/gssrl.82.1.9

Shimizu, K., Yagi, Y., Okuwaki, R., \& Fukahata, Y. (2020). Development of an inversion method to extract information on fault geometry from teleseismic data. Geophys. J. Int., 220(2), 1055-1065. doi:10.1093/gji/ggz496

Shimizu, K., Yagi, Y., Okuwaki, R., \& Fukahata, Y. (2021). Construction of fault 
geometry by finite-fault inversion of teleseismic data. Geophys. J. Int., 224(2), 1003-1014. doi:10.1093/gji/ggaa501

Sokos, E. N., \& Zahradnik, J. (2008). ISOLA a Fortran code and a Matlab GUI to perform multiple-point source inversion of seismic data. Comput. Geosci., 34(8), 967-977. doi:10.1016/j.cageo.2007.07.005

Tadapansawut, T., Okuwaki, R., Yagi, Y., \& Yamashita, S. (2021). Rupture Process of the 2020 Caribbean Earthquake Along the Oriente Transform Fault, Involving Supershear Rupture and Geometric Complexity of Fault. Geophys. Res. Lett., 48(1), 1-9. doi:10.1029/2020GL090899

U.S. Geological Survey Earthquake Hazards Program. (2017). Advanced National Seismic System (ANSS) Comprehensive Catalog of Earthquake Events and Products. doi:10.5066/F7MS3QZH

Vallée, M. (2013). Source time function properties indicate a strain drop independent of earthquake depth and magnitude. Nat. Commun., 4, 1-6. doi:10.1038/ncomms3606

Vallée, M., Charléty, J., Ferreira, A. M., Delouis, B., \& Vergoz, J. (2011). SCARDEC: A new technique for the rapid determination of seismic moment magnitude, focal mechanism and source time functions for large earthquakes using bodywave deconvolution. Geophys. J. Int., 184(1), 338-358. doi:10.1111/j.1365246X.2010.04836.x

Yagi, Y., \& Fukahata, Y. (2011). Introduction of uncertainty of Green's function into waveform inversion for seismic source processes. Geophys. J. Int., 186(2), 711720. doi:10.1111/j.1365-246X.2011.05043.x

Yamashita, S., Yagi, Y., Okuwaki, R., Shimizu, K., Agata, R., \& Fukahata, Y. (2021). Consecutive ruptures on a complex conjugate fault system during the 2018 Gulf of Alaska earthquake. Sci. Rep., 11(1), 5979. doi:10.1038/s41598-02185522-w

Ye, L., Lay, T., Bai, Y., Cheung, K. F., \& Kanamori, H. ～(2017). The 2017 Mw 8.2 Chiapas, Mexico, Earthquake: Energetic Slab Detachment. Geophys. Res. Lett., 44(23), 11,824-11,832. doi:10.1002/2017GL076085 